\title{
Comparative Efficiency of Summer Stress Busting Phytochemicals Supplemented in Feed to Improve Production Performance of Broiler
}

\author{
N. Brindha*, C. Balan and C. Sabapathi \\ Department of Veterinary and Animal science, Tamil Nadu Agricultural University, \\ Coimbatore-641 003, Tamil Nadu, India \\ *Corresponding author
}

\author{
A B S T R A C T
}

\section{Keywords}

Aloe vera, Body weight gain, Butter milk, Carcass yield, Growth performance, Turmeric powder.

Article Info

Accepted:

26 October 2017

Available Online:

10 December 2017
An experiment was conducted to analyse the effects of dietary inclusion of Aloe Vera, Turmeric powder and buttermilk on growth performance, feed conversion ratio and carcass yield in broiler chicken. The experiment involved two hundred Cobb 400 broiler chicks which were used on complete randomized design in 4 treatments with 5 replicates, each consisting of 10 broiler chicks. The groups included the control group (basal diet), Aloe vera group (basal diet $+1 \%$ aloe vera in drinking water), Turmeric powder group (basal diet $+0.5 \%$ turmeric powder in feed), Buttermilk group (basal diet $+1 \%$ buttermilk in drinking water). The experiment lasted for 35 days during which the following parameters were collected: body weight gain, feed conversion ratio and carcass yield. The highest body weight gain (in $\mathrm{g}$ ) was noticed in $\mathrm{T}_{2}(1875 \pm 41.22)$ and $\mathrm{T}_{1}(1811 \pm 47.36)$ followed by $\mathrm{T}_{3}(1746 \pm 64.21)$ and $\mathrm{T}_{4}(1737 \pm 54.49)$ at fifth week age of broiler chicken. Lowest FCR (in g) was noticed in $\mathrm{T}_{3}(1.826 \pm 0.020)$ followed by $\mathrm{T}_{2}, \mathrm{~T}_{1}$ and $\mathrm{T}_{4}$ for $1.853 \pm 0.020$, $1.880 \pm 0.031$ and $1.938 \pm 0.022$ respectively. The highest carcass yield (in $\mathrm{g}$ ) was noticed in $\mathrm{T}_{2}(1454.67 \pm 40.30)$ followed by $\mathrm{T}_{3}, \mathrm{~T}_{1}$ and $\mathrm{T}_{4}$ for $1429.16 \pm 32.24,1394.83 \pm 42.58$ and $1351.50 \pm 22.87$ respectively. Similarly, the highest dressing percentage was noticed in $\mathrm{T}_{3}$ (72.45 \pm 1.41 ) followed by $\mathrm{T}_{2}, \mathrm{~T}_{4}$ and $\mathrm{T}_{1}$ for $70.93 \pm 0.98,70.85 \pm 0.48$ and $69.43 \pm 0.65$ respectively.

\section{Introduction}

Poultry sector is one of the fastest growing sectors in the production of food animals in India. Growth promoters are agents added to animal feeds in order to enhance the feed conversion efficiency for increased formation of muscles, fat and body growth in feed-lot animals, including poultry. Antibiotic growth promoters (AGP) have been widely used in practice in the poultry and other livestock feeds for years. However, continuous and sub-therapeutic uses of AGP led to the development of undesirable antibiotic resistance in poultry. Various commonly used AGPs are prebiotics, probiotics, synbiotics, enzymes, acidifiers and phytobiotics. Dairy products such as yogurt, whey, curd, buttermilk used as probiotics which contain Rod shaped lactic acid bacteria of the genus Lactobacillus are the most important type of bacteria found in the digestive tract of birds. Either whole plants, parts of plants or essential oils can be used as phytobiotics. Their mechanism of action involves improved consumption and conversion of food, 
digestibility, weight gain and excellent antioxidant properties for broiler chickens. So in this experiment we selected Aloevera, Curcumin and buttermilk for the research purpose.

\section{Materials and Methods}

\section{Experimental birds}

Day-old straight-run broiler chicks (Vencobb 400) obtained from Private Hatcharies, were utilized in the biological trial. The birds were reared in deep litter system under standard management practices upto six weeks of age at Department of Veterinary and Animal Sciences, Tamil Nadu Veterinary and Animal Sciences, Coimbatore, 3. Feed and water were provided ad libitum. The experimental birds were vaccinated against Ranikhet disease on day 7 and 21 and against Infectious bursal disease on day 14 and 28 .

\section{Experimental design}

Two hundred numbers of day-old broiler chicks were weighed and randomly allotted to four groups with five replicates of ten chicks each based on the body weight.

\section{Experimental diet}

The experimental diets were formulated according to the standards prescribed in the breeder's manual and fed to the birds as per the following schedule. Broiler birds were given broiler pre-starter feed from 0 to $2^{\text {nd }}$ week and broiler starter diet from $2^{\text {nd }}$ to $4^{\text {th }}$ week and broiler finisher feed from $4^{\text {th }}$ to $6^{\text {th }}$ week of age. The Aloe vera, Turmeric powder and butter milk were supplemented as mentioned below.

At the end of every week, body weight of individual bird was recorded and body weight gain, feed intake was recorded and feed conversion ratio of each group was calculated. Slaughtering of birds for experiment purpose.

\section{Review of Literature}

\section{The effect of aloe vera on growth performance in broiler chicken}

Waihenya et al., (2002) reported that the guts of Aloe secundiflora supplemented chickens were lined with a layer of Aloe material leads to decreased mortality rate during Salmonella infection.

Jagmohan Singh et al., (2003) found that administration of aloevera in drinking water of broiler leads to increase the dressing percentage.

Banna et al., (2013) found that inclusion of $0.5 \%$ combination of aloevera and Allium sativum in broiler feed diet leads to decreased shedding of faecaloocyst of Eimeria spp. And also improve feed conversion ratio.

According to Mehala and Moorthy (2008) observed that addition of aloevera in broiler feed leads to maintained beneficial microbial population, improve feed intake and efficient digestion.

According to Darabighane and Nahashon (2014) reported that addition of Aloe vera in broiler diet improve intestinal health, immune system response, growth performance and control coccidiosis.

According to Rozheh (2015) said that addition of $1.5 \%$ of Aloe vera gel in drinking water and $1.5 \%$ of garlic powder in diet of broiler birds reared for 42 days, lead to improve feed intake, low feed conversion ratio and increased body weight.

Meisam et al., (2016) concluded that addition of $1 \%$ of Aloevera gel in broiler drinking 
water act as an alternative source for antibiotic growth promoter.

\section{The effect of turmeric powder on growth} performance in broiler

Samarasinghe et al., (2003) revealed that addition of $1 \mathrm{~g} / \mathrm{kg}$ of turmeric root powder in broilerfeed leads reduced energy and protein utilization and fat deposition.

Kumar et al., (2005) observed that significant increase in weight gain in broiler chicks fed with turmeric powder $(1 \mathrm{~g} / \mathrm{kg}$ of diet) and also reduced mortality rate during summer season.

Durrani et al., (2006) stated that supplementation of turmeric at the rate of $0.5 \%$ level resulted in better feed efficiency.

Emadi and Kermanshahi (2007) indicated that addition of turmeric rhizome powder in the broiler feed diet leads to increase activity of AST enzyme and decreased ALT enzyme activity.

Hosseini-Vashan et al., (2012) showed that activity of blood enzymes including ALT and AST were suppressed by the supplementation of turmeric rhizome powder to heat stressed broiler diet.

Candra and Putri (2013) found that administration of turmeric extract with ethanol would increase body weight gain, feed efficiency, reduce mortality by means of prevent from coccidiosis.

\section{The effect of butter milk on growth} performance in broiler chicken

Improving feed quality by increasing protein level in rations may enhance growth performance and increase muscle growth in broilers (Firman and Boling, 1998). Gulsen et al., (2002) reported that the improvement observed in broilers fed with lactose during the starter period, could be attributed to an increase in intestinal villi length which was assumed to improve nutrient absorption and bird performance.

Inclusion of $0.02 \%$ dried buttermilk powder also exerts an improvement in body weight gain, feed conversion ratio to broiler chicks (Kheiri et al., 2015).

\section{Statistical methods}

Statistical analysis was done using completely randomized design, one-way classification as perthe procedure given by Snedecor and Cochran (1994). Significant differences among different treatments were identified using Duncan's Multiple Range Test and a $\mathrm{p}<0.05$ was considered to be statistically significant.

\section{Results and Discussion}

\section{Effect on production performance}

\section{Body weight gain (g)}

The effect of supplementation of Aloe vera, turmeric powder and butter milk on the mean body weight gain $(\mathrm{g})$ of broiler chicken is presented in Table 1. The result showed there was no significant different noticed at 1, 2, 3 and fourth weeks age of all treatment groups. However, the highest body weight gain (in g) was noticed in $\mathrm{T}_{2}(1875 \pm 41.22)$ and $\mathrm{T}_{1}$ (1811 \pm 47.36$)$ followed by $\mathrm{T}_{3}(1746 \pm 64.21)$ and $\mathrm{T}_{4}(1737 \pm 54.49)$ at fifth week age of broiler chicken. Present findings increasing body weight using turmeric powder in broiler diet was agreed with Durrani et al., (2006) Herawati (2010) and Elmakki et al., (2013). Also, results of the present finding increased body weight by using Alovera in broiler diet agreed with Lin et al., (2005) and Gang et al., (2014) observed increased weight gain. 


\section{Experimental diet}

\begin{tabular}{|l|l|}
\hline Treatment Groups & Experimental diets \\
\hline $\mathbf{T}_{\mathbf{1}}$ & Basal diet \\
\hline $\mathbf{T}_{\mathbf{2}}$ & Basal diet (with Aloe Vera 1\% in drinking water) \\
\hline $\mathbf{T}_{\mathbf{3}}$ & Basal diet (with Ground Turmeric Powder 0.5\% in feed) \\
\hline $\mathbf{T}_{\mathbf{4}}$ & Basal diet (with Buttermilk 1\% in drinking water) \\
\hline
\end{tabular}

Table.1 Least square Means ( \pm S.E.) body weight (g) at different group of broiler chicken

\begin{tabular}{|l|l|l|l|l|}
\hline Age & $\mathbf{T}_{\mathbf{1}}$ & $\mathbf{T}_{\mathbf{2}}$ & $\mathbf{T}_{\mathbf{3}}$ & $\mathbf{T}_{\mathbf{4}}$ \\
\hline Week 1 & $146 \pm 4.76^{\mathrm{a}}$ & $155 \pm 4.76^{\mathrm{a}}$ & $149 \pm 6.75^{\mathrm{a}}$ & $169 \pm 4.58^{\mathrm{a}}$ \\
\hline Week 2 & $362 \pm 20.54^{\mathrm{a}}$ & $402 \pm 9.64^{\mathrm{a}}$ & $389 \pm 18.65^{\mathrm{a}}$ & $401 \pm 10.27^{\mathrm{a}}$ \\
\hline Week3 & $800 \pm 17.19^{\mathrm{a}}$ & $796 \pm 13.76^{\mathrm{a}}$ & $802 \pm 18.12^{\mathrm{a}}$ & $813 \pm 19.61^{\mathrm{a}}$ \\
\hline Week 4 & $1290 \pm 25.34^{\mathrm{a}}$ & $1351 \pm 26.60^{\mathrm{a}}$ & $1280 \pm 40.33^{\mathrm{a}}$ & $1259 \pm 47.99^{\mathrm{a}}$ \\
\hline Week 5 & $1811 \pm 47.36^{\mathrm{b}}$ & $1875 \pm 41.22^{\mathrm{b}}$ & $1746 \pm 64.21^{\mathrm{a}}$ & $1737 \pm 54.49^{\mathrm{a}}$ \\
\hline
\end{tabular}

Means bearing same superscript do not differ significantly otherwise significant at $5 \%$ level of significance

Table.2 Least square Means ( \pm S.E.) feed conversion ratio $(g)$ at different group of broiler chicken

\begin{tabular}{|l|l|l|l|l|}
\hline Age & T1 & T2 & T3 & T4 \\
\hline Week 1 & $0.142 \pm 0.003^{\mathrm{a}}$ & $0.136 \pm 0.001^{\mathrm{a}}$ & $0.140 \pm 0.003^{\mathrm{a}}$ & $0.138 \pm 0.001^{\mathrm{a}}$ \\
\hline Week 2 & $0.394 \pm 0.002^{\mathrm{a}}$ & $0.384 \pm 0.002^{\mathrm{a}}$ & $0.378 \pm 0.003^{\mathrm{a}}$ & $0.389 \pm 0.005^{\mathrm{a}}$ \\
\hline Week 3 & $0.854 \pm 0.010^{\mathrm{a}}$ & $0.812 \pm 0.015^{\mathrm{a}}$ & $0.836 \pm 0.007^{\mathrm{a}}$ & $0.864 \pm 0.012^{\mathrm{a}}$ \\
\hline Week 4 & $1.386 \pm 0.018^{\mathrm{a}}$ & $1.342 \pm 0.025^{\mathrm{a}}$ & $1.378 \pm 0.013^{\mathrm{a}}$ & $1.426 \pm 0.018^{\mathrm{b}}$ \\
\hline Week 5 & $1.880 \pm 0.031^{\mathrm{a}}$ & $1.853 \pm 0.020^{\mathrm{a}}$ & $1.826 \pm 0.020^{\mathrm{a}}$ & $1.938 \pm 0.022^{\mathrm{b}}$ \\
\hline
\end{tabular}

Means bearing same superscript do not differ significantly within the rows otherwise significant at $5 \%$ level of significance.

Table.3 Least square Means ( \pm S.E.) of pre-slaughter, carcass weight $(g)$ and dressing percentage at different treatment of broiler chicken

\begin{tabular}{|l|l|l|l|}
\hline Treatment & Pre-slaughter weight & Carcass weight & Dressing \% \\
\hline T1 & $2025.36 \pm 46.60^{\mathrm{a}}$ & $1394.83 \pm 42.58^{\mathrm{b}}$ & $69.43 \pm 0.65^{\mathrm{a}}$ \\
\hline T2 & $2088.21 \pm 62.04^{\mathrm{a}}$ & $1454.67 \pm 40.30^{\mathrm{b}}$ & $70.93 \pm 0.98^{\mathrm{a}}$ \\
\hline T3 & $2025.15 \pm 44.54^{\mathrm{a}}$ & $1429.16 \pm 32.24^{\mathrm{b}}$ & $72.45 \pm 1.41^{\mathrm{b}}$ \\
\hline T4 & $1925.08 \pm 31.06^{\mathrm{a}}$ & $1351.50 \pm 22.87^{\mathrm{a}}$ & $70.85 \pm 0.48^{\mathrm{a}}$ \\
\cline { 1 - 3 }
\end{tabular}

Means bearing same superscript do not differ significantly within the coloumns otherwise significant at $5 \%$ level of significance 
Turmeric powder and aloe vera has the ability to stimulate digestive enzymes, bile production in liver, antioxidant effect and depress pathogenic microbial flora in the small intestine it may be the reasons for increasing body weight gain in broiler chicken.

\section{Feed conversion ratio (FCR)}

The effect of supplementation of Aloe vera, turmeric powder and butter milk on the mean Feed conversion ratio of broiler chicken at different age is presented in Table 2. The present result revealed, the significant different between treatment groups was noticed at fourth and fifth week of age but no significant different noticed at 1,2 and third week of age in broiler chicken. Similarly, the lowest FCR (in g) was noticed in $\mathrm{T}_{3}$ (1.826 \pm 0.020$)$ followed by $T_{2}, T_{1}$ and $T_{4}$ for $1.853 \pm 0.020,1.880 \pm 0.031$ and $1.938 \pm 0.022$ respectively.

The better feed conversion ratio (FCR) by using butter milk, turmeric powder and Aloe vera in broiler diet were agreed with Herawati (2010) and Elmakki et al., (2013).

\section{Dressing percentage (\%)}

The effect of supplementation of Aloe vera, turmeric powder and butter milk on the mean dressing percentage (\%) of broiler chicken is presented in Table 3. The result showed, there was significant different between treatment for carcass yield and dressing percentage at 38 days age of broiler chicken but no significant different was noticed between treatment for pre-slaughter live weight.

The highest carcass yield (in $\mathrm{g}$ ) was noticed in $\mathrm{T}_{2}(1454.67 \pm 40.30)$ followed by $\mathrm{T}_{3}, \mathrm{~T}_{1}$ and $\mathrm{T}_{4}$ for $1429.16 \pm 32.24, \quad 1394.83 \pm 42.58$ and $1351.50 \pm 22.87$ respectively. Similarly, the highest dressing percentage was noticed in $\mathrm{T}_{3}$
(72.45 \pm 1.41 ) followed by $\mathrm{T}_{2}, \mathrm{~T}_{4}$ and $\mathrm{T}_{1}$ for $70.93 \pm 0.98, \quad 70.85 \pm 0.48$ and $69.43 \pm 0.65$ respectively.

The highest dressing percentage was noticed in $\mathrm{T}_{3}$ (butter milk with basal diet) agreed with Kermanshahi and Rostami (2006), Al-Asadi et al., (2008) and Majewska et al., (2009).

The treatment, with feeding of butter milk 1 per cent mixed with drinking water showed higher dressing percentage. The improvement observed in broilers fed with butter milk during the starter period, could be attributed to an increase in intestinal villi length which was assumed to improve nutrient absorption and bird performance.

In conclusion, present study indicate the significance of Aloe vera, turmeric powder, butter milk feed inclusions improved the FCR, body weight, dressing percentage respectively. Hence Aloe Vera, Turmeric powder and Buttermilk can be added as supplementary food in basal diet and drinking water to obtain above discussed positive effects.

\section{References}

Al-AsadiAdnanN, Al- KabbiHaiderT, KalfAhmed K. MajeedAnmar A.2008. Effect off Supplemental Fresh Liquid Whey to Drinking Water on Broiller Performance. https://www.researchgate. net/publication/3121925062:121-121.

BabakDarabighane and Samuel N. Nahashon. 2014. A review a effects of Aloe vera as a feed additive in broiler chicken diets. Ann.Animal.Sci.14(3): 491-500.

Candra AA and Putri DD. 2013. The efficacy of turmeric extract against experimentally induced Eimeria maxima infection in broiler. Bangl.J.Vet.Med. 11(2): 93-95.

Durrani FR, Mohammad Ismail, Asad Sultan, 
Suha SM, Nailachand and Durrani Z. 2006. Effect of different levels of feed added turmeric (Curcuma longe) on the performance of broiler chick. Journal of Agricultural and biological science. 1(2): 9-11.

El-Banna HA, Amera Abd EI Latif and Soliman. 2003. Anticoccidial activity of Allium sativum and Aloe vera in broilers. IJAVMS 7(4): 111-125.

ElmakkiAbdallah M., AbdelAtti1Khadig A, DousaBakheit M, Elagib Hind AA, MalikHuwaida E E and Elamin Khalid M.2013.Effects of Dietary Ground Ginger (Zingiber officinale) Root Additive on Broiler performance. Global Journal of Animal Scientific Research. 1(1): 76-83.

Emadi M and Kermanshahi H. 2007. Effects of turmeric rhizome powder on the activity of some blood enzymes in broiler chickens. International Journal of Poultry Science. 6:48-51.

Firman, J.D. and S.D. Boling, 1998.Ideal protein in turkeys. Poult. Sci., 77: 105110.

Gowda NKS, Ledoux DR, Rottinghaur GE, Bermudez AJ, Chen YC. 2008. Efficancy of turmeric (Curcuma longa) containing a known level of Curcumin and a hydrated sodium Calcium Aluminosilicate to Ameliorate the adverse effects of aflatoxin in broiler chicks. Poultry Science, 87(6):11251130.

Gulsen N, Coskun B, Umucalilar HD, Inal F, Boydak M, 2002. Effect of lactose and dried whey supplementation on growth performance and histology of the immune system in broilers. Arch. Anim. Nutr. 56:131-139

Herawati2010.The Effect of Feeding Red Ginger as Phytobiotic on Body Weight Gain, Feed Conversion and Internal Organs Condition of Broiler. International Journal of Poultry Science.
9(10): 963-967.

Hosseini-Vashan, SJ, Golian A, Yaghobfar, A, Zarban A, Afazali N and Esmaeiilinasab P. 2012. Antioxidant status, immune system, blood metabolites and carcass characteristics of broiler chickens fed turmeric rhizome powder under heat stress. Afri. Journal of Biotech. 11(94): 16118-16125.

Jagmohan Singh, Koley KM, Khushboo Chandrasekar and Nileshkumar S. Pagrut, 2013. Effect of aloe vera on dressing percentage and haematobiochemical parameters of broiler chickens. Veterinary World. 6: 803-806.

Kermanshahi $\mathrm{H}$ and Rostami $\mathrm{H}$. 2006. Influence of supplemental dried whey on broiler performance and cecal flora. Int. J. Poult. Sci. 5: 538-543.

Kheiri F, Rahimian Y and Nasr J. 2015. Application of sumac and dried whey in female broiler feed. Arch. Anim. Breed. 58: 205-210.

Kumar M, Chodhary RS and Vaishnav JK. 2005. Effect of supplemental prebiotic, probitic and turmeric in diet on the performance of broiler chicks during summer. Ind.J.Poult.Sci. 40: 137-141.

Lin J, Zhang FY, Xu Y, Ting ZX, Po YD. 2005. Effects of gel, polysaccharide and acemannan from Aloe vera on broiler gut flora, microvilli density, immune function and growth performance. Chin. J. Vet. Sci. 25: 668-671.

Majewska D, Jakubowska M, Ligocki M, Tarasewicz Z, Szczerbińska D, Karamucki T, Sales J. 2009. Physicochemical characteristics, proximate analysis and mineral composition of ostrich meat as influenced by muscle. Food Chemistry. 117: 207-211.

Mehala C andMoorthy M. 2008. The effects of herbs and their associated essential oils on the performance, dietary digestibility and gut microflora in 
chickens from 7-28 days of age. Br. Poult Sci. 48:496-506.

MeisamShokraneh, GholamrezaGhalamkari, MajidToghyani and NasirLandy. 2016. Influence of drinking water containing Aloe vera (Aloe barbadensis Miller) gel on growth performance intestinal microflora and humoral immune response of broilers. J. Vet world. 9(11): 1197-1203.

Rozbeh Fallah. 2015. Effect of adding Aloe vera gel and garlic powder on performance and liver functions of broiler chickens. Global journal of Animal scientific Research. 2: 491-496.

Samarasinghe K, Wenk C, Silva K F S T, Gunasekara J M D M. 2003. Turmeric (Curcuma longa) root powder and mannan oligosaccharides as alternatives to antibiotics in broiler chicken diets, Asian-Australian journal of Animal sciences.16 (10):1495-1500.

Snedecor, G.W. and Cochran, W.B. (1994) Statistical Methods. 8th ed. The Iowa State University Press, Ames, IOWA, USA.

Tang Zhi-gang Naem M, Chao W, Tian W and Zhou Yan-min. 2014. Effect of dietary probiotics supplementation with different nutrient density on growth performance, nutrient retention and digestive enzyme activities in broilers. The Journal of Animal and Plant Sciences. 24(5): 1309-1315.

Waihenya RK, Mtambo M M, NKwengulila G, Minga U M. 2002. Efficacy of crude extract of Aloe secundiflora against Salmonella gallinarum in experimentally infected free range chicken in Tanzania. Journal of Ethinopharmacology. 7: 317-323.

\section{How to cite this article:}

Brindha, N., C. Balan and Sabapathi, C. 2017. Comparative Efficiency of Summer Stress Busting Phytochemicals Supplemented in Feed to Improve Production Performance of Broiler. Int.J.Curr.Microbiol.App.Sci. 6(12): 3384-3390. doi: https://doi.org/10.20546/ijcmas.2017.612.394 